\title{
F. Schiemer, D. Simon, U.S. Amarasinghe \& J. Moreau (eds): Aquatic ecosystems and development: comparative Asian perspectives
}

\author{
Biology of inland waters series, Backhuys Publishers, Leiden, The Netherlands/ \\ Margraf Publishers, Weikersheim, Germany, 2008, 508 pp, 181.90 EURO \\ (incl. VAT)
}

\author{
Ramesh D. Gulati \\ Published online: 28 January 2009 \\ (C) The Author(s) 2009. This article is published with open access at Springerlink.com
}

This publication is the result of fruitful collaborative project FISHSTRAT funded by the EU's INCO-DC programme. This project may be regarded as the continuation of an earlier tropical limnology project, the famous Parakrama Samudra reservoir project (Schiemer 1983), which studied this beautiful, ancient reservoir in the north-east of Sri Lanka more than 25 years ago. The results of this study and hypotheses emerging from these, inspired a whole generation of tropical limnologists. As for the Parakrama Samudra project, the idea for FISHTRAT project came from three prominent members of the earlier Pakrama Samudra team: Nan Duncan (Holloway College, UK), Fritz Schiemer (University of Vienna, Austria) and Upali Amarasinghe (Kellaniya University, Sri Lanka). They originally wanted to limit the project to Sri Lanka, but because the EU rules stipulated three countries in the same region, they included Thailand and Philippines as well.

The book is dedicated to late Annie (Nan) Duncan, who coordinated the FISHSTRAT project until she became ill. This ambitious project had the aim to gain via multi-disciplinary and system-oriented research a better insight into the complex interrelationships in freshwater systems for formulating sustainable development policy recommendations for tropical water bodies. Research was carried out

R. D. Gulati $(\bowtie)$

Centre for Limnology, Nieuwersluis, The Netherlands

e-mail: R.Gulati@nioo.knaw.nl during 1998-2002 in five water bodies (four reservoirs and one lake) and their catchment areas in Sri Lanka, Thailand and the Philippines. This system-oriented approach integrated, limnology, fish ecology, fisheries, aquaculture and socio-economics conditions of the riparian fishing communities. To facilitate comparisons, the same methods, tools, gear and research strategy were used for all water bodies. This northsouth partnership involved researchers from five European and three Asian countries. In total, 33 authors from 16 institutions were involved in writing the 23 book chapters.

Limnology, including fish ecology, dominates 14 chapters, whereas fisheries and socio-economics are each represented by three chapters. Aquaculture with one chapter is clearly under represented. The whole effort is remarkable, taking into account the huge difficulties of coordinating the large number of people with different cultures and perceptions.

This 23-chapter book has six sections. The first section (chapters 2-4) provides a general description of physical, hydrological and catchment characteristics of the water bodies. The second section (chapters 5-9) compares different aspects of the ecosystems. It focuses on phytoplankton community structure and factors governing phytoplankton primary production. Role of bacterial activity in the detrital food chain, seasonality, biomass and production of zooplankton populations are also discussed. The third section (chapters 10-14) focuses on fish ecology, use of hydro-acoustics for assessing fish stocks, feeding 
ecology of fish assemblages, diet predictions on basis of ecomorphology and selective feeding of small zooplanktivorous fish; modelling approaches are used to assess daily feeding patterns and food consumption. The fourth section (chapters 15-17) addresses fisheries and aquaculture, analysing capture fisheries, population dynamics of non-exploited and underexploited fish species, population dynamics of commercially important species. The fifth section (chapters 18-20) examines the socio-economic aspects of aquaculture, fisheries and fish trading. Chapters 21-23 form the last section where the principal findings and conclusions from each disciplinary area are collated for a holistic analysis.

Limnology that is regarded as the scientific basis for aquatic resource management receives a great attention. Rightly, the ecosystem-oriented limnological approach employed here greatly helps to understand aspects such as the habitat conditions for the fish assemblages, the carrying capacity of the resource base, food web structure and the efficiency of its utilization by the fish, and unfilled niches versus untapped resources. The ecosystems of the three countries show both differences and similarities. As expected, the large and deep (max. depth $198 \mathrm{~m}$ ) crater lake, L. Taal (Philippines), differs from the Sri Lankan and Thai reservoirs in many respects. Areal zooplankton production in Lake Taal is very high relative to the chlorophyll concentration per unit volume. This is because the mixing depth of the lake is ca. $100 \mathrm{~m}$, with zooplankton inhabiting the upper 80-m layers. In the shallower Sri Lankan reservoirs Minneriya and Udawalawe in Sri Lanka and in Ubolratana reservoir in Thailand, nutrient and chlorophyll concentrations are high at the end of the dry season when water level is low, which demonstrates the importance of internal nutrient loading. In the Sri Lankan reservoirs, but not in Lake Taal in Thailand, high flushing rates at the start of the dry season reduce chlorophyll levels and primary production.

Fish studies were based on both traditional gill netting, beach seining and use of acoustics (Simrad EY 500 split beam echo sounder, Chapter 10). This last technique offers several advantages over the other techniques. The acoustics enable to search a large volume of water in a relatively short time and give a better insight into the spatial distribution of the fish and allows accurate estimates of their size distribution and biomass. A major drawback, however, is that it is not easy to identify all fish species so that the acoustics had to be supplemented by experimental fishing. The overall size distribution of the fish communities was similar in all the waters studied. Small-sized fish comprised both the highest numbers and biomass, because of this and their high $\mathrm{P} / \mathrm{B}$ ratios (chapter 21), small fish play a pronounced role in the food web. The fish communities in the three countries also differ: Thailand with 75 fish species had the highest biodiversity and Sri Lankan reservoirs with 31 species the lowest. The trophic structure of the fish communities differed markedly: whereas herbivores (tilapia, small carps) dominated in all Sri Lankan reservoirs, zooplanktivorous clupeids dominated in Lake Taal (Sardinella tawilis) and Ubolratana reservoir (Clupeichthys aesarnensis). Except for Lake Taal, 'zooplanktivorous' fish in Sri Lanka and Thailand mainly feed on adult chironomid midges rather than on zooplankton.

The fisheries studies revealed several surprises. Despite the ancient tradition (ca. 2,000 years) of reservoir construction in Sri Lanka, inland fishery is a recent practice in this country. It has developed mainly due to the migration of coastal marine fisher families to the reservoirs after tilapia (Oreochromis mossambicus) was introduced in the early 1950s. The tilapia species, which form the main fishery in Sri Lanka, feed on lower trophic levels so that their annual yield is relatively high, much higher than the yield in Ubolratna, where the exploited fish populations feed higher in the food web. The fishery in Ubolratana and Lake Taal is very diverse probably because of the large size of the water bodies and greater fish diversity. Whereas in Ubolratana the yield is dominated by benthivorous fish species in Lake Taal, the pelagic zooplanktivores dominate the fish yield. Total fish yields are the highest in the Philippines and the lowest in Thai reservoirs. The income of fishermen varies markedly, being the highest in Sri Lanka where it is also well above the average poverty line and the lowest at Ubolratana in Thailand.

Aquaculture was only important in Lake Taal with some 10,000 cages (chapter 18 ). It increased production of total lacustrine fish substantially and offered a good income to the investors. However, the dense aggregations of cages in certain areas of the lake led to deterioration of water quality (anoxic conditions), causing fish kills in the both lake and cages. 
Surprisingly, the FISHSTRAT researchers did not find a correlation between the resource potential and its utilization by the fishermen. In other words, the limnological conditions could not explain the differences in fish yields among the studied water bodies. Most likely, the choice of which species to target is predominantly influenced by social and economical factors. This is because the operation of capture fisheries in these water bodies mainly depends on tradition and the availability of gear rather than insight into the fish stocks. As a result, fisheries in all studied water bodies are restricted to a relatively small number of fish species, and only a small part of the available fish production is actually harvested. Thus, there are untapped resources that are not utilized by the fishery. This is an important revelation, especially for Sri Lanka where minor carps dominate the fish production but the fishery is concentrated on two tilapia species only. It is even clearer in Thailand where only a small number of the 75 species is harvested. The editors conclude that the interactions among managers, stakeholders and researchers need to be improved to optimise utilization of the resources; they recommend (chapter 23) establishing a co-management forum for all exploited water bodies in the three Asian countries. This, indeed, seems to be the only rational solution, since an optimal resource use includes ecological, environmental, economical as well as social sustainability.

The book is carefully edited and generally reads quite well. The diverse contributions are well integrated as the book chapters are very well crossreferred to one and other, and the last section (chapters 21, 22, 23) integrates the most important information. The book presents a large collection of interesting information and richly contributes to present knowledge and understanding of system dynamics in tropical lakes and reservoirs. The bottom-line: it is a good value for money for the fundamental limnologists/aquatic ecologists and the inland fisheries biologists. However, considering the central question addressed in this book, i.e. formulating appropriate sustainable development policy, for improving management and to increase the fish yields and the income of the fishermen, the whole FISHSTRAT project is obviously a bit biased. Somewhat exaggerated emphasis in the book is laid on limnology and fish ecology, and consequently this has taken its toll on the more essential issues as aquaculture and social-economical aspects of this study.

I would recommend this book to graduate students and researchers alike in tropics in the fields of limnology, fish community ecology and inland fisheries and to researchers engaged in multi-disciplinary and system-oriented studies for understanding the complex interrelationships in freshwater systems, especially if the study aims are to improve resource management.

I am highly grateful to my colleague Koos Vijverberg for his constructive criticism of an earlier version of this review.

Open Access This article is distributed under the terms of the Creative Commons Attribution Noncommercial License which permits any noncommercial use, distribution, and reproduction in any medium, provided the original author(s) and source are credited.

\section{Reference}

Schiemer F (ed) (1983) Limnology of Parakrama SamudraSri Lanka. A case study of an ancient man-made lake in the tropics. Dr. W. Junk Publishers, The Hague, p 236 